\title{
Effect of Roasting Temperature for Copper Leaching of Sulfide Concentrate by Combined Methods
}

\author{
Lkhamtogmid Nyamjargal1*, Ganbat Batdemberel ${ }^{2}$, Gunchin Burmaa ${ }^{3}$, Dashdendev Burmaa1 \\ ${ }^{1}$ Department of Chemical Engineering, School of Applied Sciences, MUST, Ulaanbaatar, Mongolia \\ ${ }^{2}$ Department of Physics, School of Applied Sciences, MUST, Ulaanbaatar, Mongolia \\ ${ }^{3}$ Institute of Chemistry and Chemical Technology, Mongolian Academy of Sciences, Ulaanbaatar, Mongolia \\ Email: *nyamjargal@must.edu.mn
}

How to cite this paper: Nyamjargal, L., Batdemberel, G., Burmaa, G. and Burmaa, D. (2018) Effect of Roasting Temperature for Copper Leaching of Sulfide Concentrate by Combined Methods. Open Journal of Applied Sciences, 8, 545-553.

https://doi.org/10.4236/ojapps.2018.812044

Received: November 2, 2018

Accepted: December 4, 2018

Published: December 7, 2018

Copyright $\odot 2018$ by authors and Scientific Research Publishing Inc. This work is licensed under the Creative Commons Attribution International License (CC BY 4.0).

http://creativecommons.org/licenses/by/4.0/

\begin{abstract}
This study was undertaken to develop a cost-effective method of copper leaching in sulfide concentrate involving minerals as chalcopyrite and pyrite. The combined methods involving low temperature roasting of sulfide copper minerals with potassium chlorides without the formation of sulfurous gases and their evolution into the atmosphere is suggested. The effect of experimental parameters such as a roasting temperature and time has been presented and discussed in detail. This study was carried out in the roasting temperature range $400^{\circ} \mathrm{C}-600^{\circ} \mathrm{C}$ and roasting time ranges $1-4 \mathrm{~h}$ with potassium chloride. The obtained cake is leached by an aqueous sulfuric acid $60 \mathrm{~g} / \mathrm{l}$ concentrated at $\mathrm{pH}=2-2.5$ and $4 \mathrm{~h}$. The concentrate, a roasting cake and after leaching solid residue were analyzed by chemical analysis, XRD and SEM-EDX. At temperature ranges $450^{\circ} \mathrm{C}-550^{\circ} \mathrm{C}$ and $3 \mathrm{~h}$ of roasting, the process is activated. The recovery of copper into the solution at optimal roasting condition $\left(500^{\circ} \mathrm{C}\right.$, roasting time $\left.3 \mathrm{~h}\right)$ is $93.2 \%$. The advantage of the developed method is that, it not requires high roasting temperature and the use of autoclave for leaching. The method gives possibility to leach the concentrate at room temperature and atmospheric pressure, which gives possibility to reduce cost of the process.
\end{abstract}

\section{Keywords}

Copper Leaching, Chlorination, Potassium Chloride, Chalcopyrite

\section{Introduction}

Copper is found in various combinations of $\mathrm{Cu}, \mathrm{Fe}, \mathrm{S}$, and other elements in na- 
ture: among these naturally occurring compounds, chalcopyrite $\left(\mathrm{CuFeS}_{2}\right)$ is an abundant source that accounts for almost $70 \%$ of all copper resources in the world [1]. The pyrometallurgical process is widely used to extract copper from chalcopyrite; however, with increasing worldwide copper production, copper ores are becoming increasingly scarce, and moresulfur dioxide $\left(\mathrm{SO}_{2}\right)$ is being released into the atmosphere [1]. Concerns over air pollution and the environmental problem of acid rain have made governments all over the world tighten their regulations regarding the emission of sulfuric dioxide [2]. Mechanochemical leaching efficiency of chalcopyrite was very low at ambient temperature, the percentages of copper dissolved after $20 \mathrm{~h}$ between $28 \%$ - 33\% [3]. Both circumstances warrant the development of enhanced copper extraction methods.

The combined methods involving low temperature roasting of sulfide copper minerals with potassium chlorides without the formation of sulfurous gases and their evolution into the atmosphere is suggested. Copper concentrates contain sulfide minerals such as chalcopyrite, pyrite, chalcosine, covelline and bornite, Therefore, the list of possible reactions accompanying their chlorinating roasting can be continued [4] [5]:

$$
\begin{gathered}
\mathrm{CuFeS}_{2}+4 \mathrm{KCl}+4 \mathrm{O}_{2}=\mathrm{CuCl}_{2}+\mathrm{FeCl}_{2}+2 \mathrm{~K}_{2} \mathrm{SO}_{4} \\
\mathrm{CuFeS}_{2}+4 \mathrm{KCl}+4 \mathrm{O}_{2}=\mathrm{CuCl}+\mathrm{FeCl}_{3}+2 \mathrm{~K}_{2} \mathrm{SO}_{4} \\
2 \mathrm{CuFeS}_{2}+8 \mathrm{KCl}+\frac{17}{2} \mathrm{O}_{2}=\mathrm{Cu}_{2} \mathrm{O}+2 \mathrm{FeCl}_{3}+4 \mathrm{~K}_{2} \mathrm{SO}_{4}+2 \mathrm{Cl} \\
\mathrm{FeS}_{2}+4 \mathrm{KCl}+4 \mathrm{O}_{2}+\mathrm{FeCl}_{2}=2 \mathrm{FeCl}_{3}+2 \mathrm{~K}_{2} \mathrm{SO}_{4} \\
\mathrm{FeS}_{2}+4 \mathrm{KCl}+4 \mathrm{O}_{2}=\mathrm{FeCl}_{3}+2 \mathrm{~K}_{2} \mathrm{SO}_{4}+\mathrm{Cl} \\
\mathrm{CuS}+2 \mathrm{KCl}+2 \mathrm{O}_{2}=\mathrm{CuCl}_{2}+\mathrm{K}_{2} \mathrm{SO}_{4} \\
\mathrm{Cu} \mathrm{S}_{2} \mathrm{~S}+2 \mathrm{KCl}+2 \mathrm{O}_{2}=2 \mathrm{CuCl}_{2}+\mathrm{K}_{2} \mathrm{SO}_{4} \\
\mathrm{CuCl}+\mathrm{Cl}=\mathrm{CuCl}_{2} \\
\mathrm{FeCl}+\mathrm{Cl}=\mathrm{FeCl}_{3}
\end{gathered}
$$

Chlorinating roasting of copper sulfide minerals under an atmosphere for removing of metals has continued to remain a subject of interest. Bayer and Weidemann have observed that the salt roasting is spontaneous for $\mathrm{KCl}$, slower for $\mathrm{NH}_{4} \mathrm{Cl}$ and variable rate for $\mathrm{NaCl}$. They have studied on salt roasting of chalcopyrite at low temperatures $(473-513 \mathrm{~K}$ ) by thermoanalytical technique [6]. The chemistry of the salt-roasting process is very complex because several processes, such as oxidation, sulphation, in situ chlorination and evaporation of volatile species, occur either simultaneously or sequentially [7]. The non-isothermal analysis confirmed the chemical control mechanism at temperatures below $620 \mathrm{~K}$ [8].

\section{Experimental}

\subsection{Materials}

Sulfide copper concentrate originating from OyuTolgoi mine, Mongolia, with $28.68 \%$ of $\mathrm{Cu}, 34.52 \%$ of $\mathrm{Fe}, 32.2 \%$ of $\mathrm{S}, 4.6 \%$ other elements were used in the 
investigation. The sample contains $21.49 \mathrm{~g} /$ ton of $\mathrm{Au}, 47.69 \mathrm{~g} /$ ton of Ag. The elemental composition of the copper concentrate was analyzed by ICP-OES. The sample was crushed and dry-sieved to different narrow size fractions, namely $-150+100,-100+50,-45+32 \mu \mathrm{m}$. The XRD of concentrate is shown in Figure 1. The copper concentrate included chalcopyrite $\left(\mathrm{CuFeS}_{2}\right) 59.56 \%$, pyrite $\left(\mathrm{FeS}_{2}\right)$ 14.23\%, hematite $\left(\mathrm{Fe}_{2} \mathrm{O}_{3}\right) 2.1 \%$ and albite $\left(\mathrm{Na}\left[\mathrm{AlSi}_{3} \mathrm{O}_{8}\right]\right) 5.95 \%$, anorthite $\left(\mathrm{CaAl}_{2} \mathrm{Si}_{2} \mathrm{O}_{8}\right) \quad 11.68 \%$, quartz $6.45 \%$ were identified by XRD. The SEM-EDX of concentrate is shown in Figure 2. The elemental composition of concentrate determined $\mathrm{Fe} 34.89 \%$, $\mathrm{Cu} 27.41 \%$ and S $26.11 \%$ from EDX analysis.

\subsection{Experimental Condition}

The $2 \mathrm{~g}$ of the sample was prepared for each roasting with potassium chloride. The concentrate $/ \mathrm{KCl}$ weight ratio was held at $1 / 0.7$. The roasting temperature was varied from $400^{\circ} \mathrm{C}$ to $600^{\circ} \mathrm{C}$, the roasting time was changed $1,2,3$ and $4 \mathrm{~h}$, and each sample was dissolved after roasting. The leaching temperature at $25^{\circ} \mathrm{C}$, the sulfuric acid concentration was $60 \mathrm{~g} / \mathrm{l}$, the solid/liquid (S/L) ratio was $=1 / 9$, the rotation speed was $450 \mathrm{r} / \mathrm{min}$ in all leaching experiments. The leaching time was $4 \mathrm{~h}$.

\section{Result and Discussion}

The effect of experimental parameters such as a roasting temperature, time have been presented and discussed in detail.

\section{Effect of Roasting Temperature and Time}

Experiments of roasting with $\mathrm{KCl}$ were performed according to the flowchart

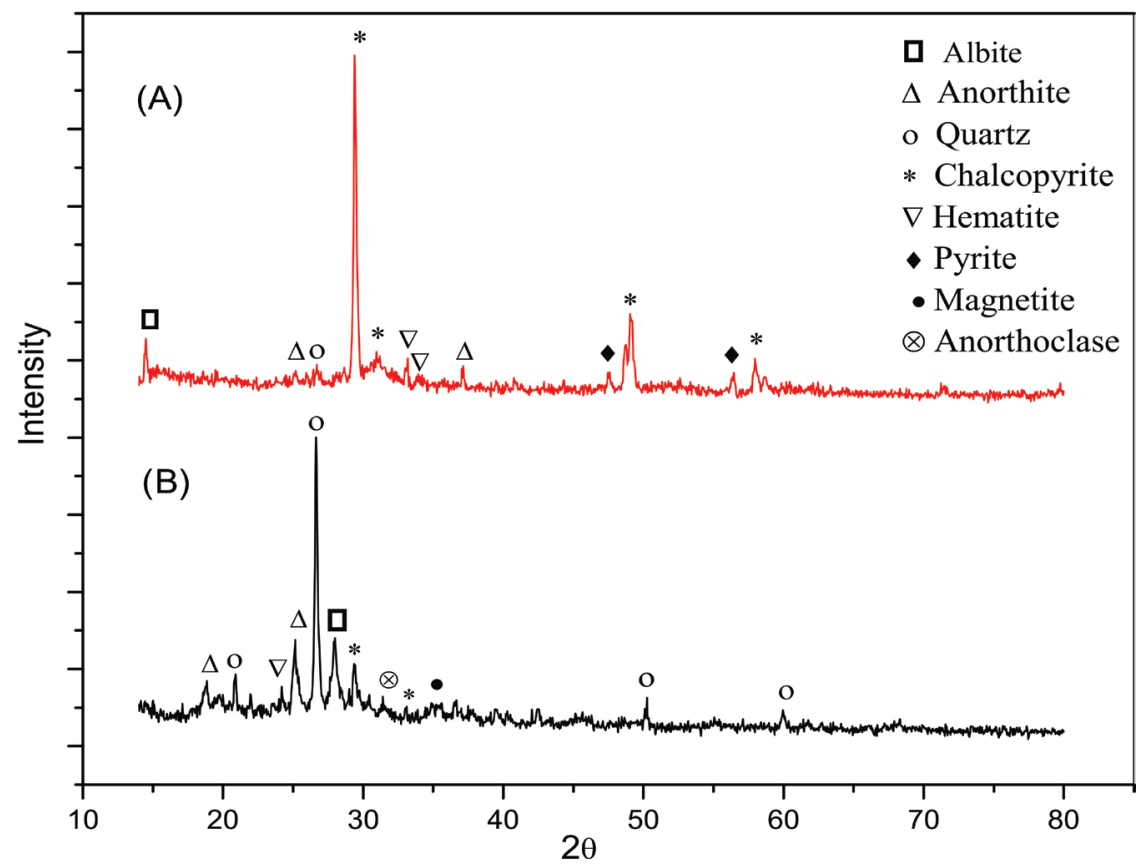

Figure 1. XRD pattern of copper concentrate (A) and copper ore (B). 


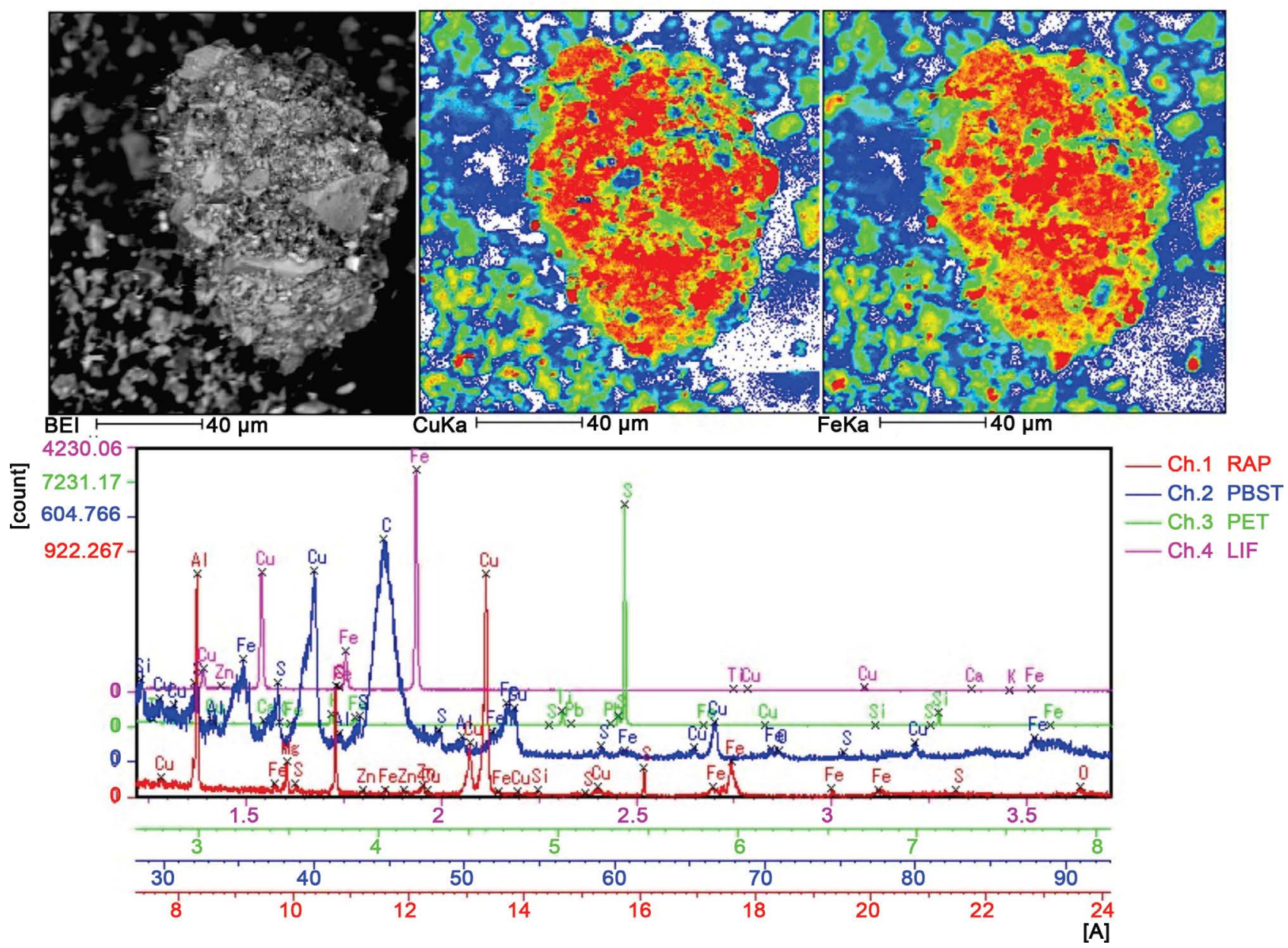

Figure 2. SEM-EDX of copper concentrate.

presented in Figure 3 at different roasting temperatures $\left(400^{\circ} \mathrm{C}-600^{\circ} \mathrm{C}\right)$ and roasting time $(1-4 \mathrm{~h})$. The roasted cake was leached at the ratio $\mathrm{S} / \mathrm{L}$ was $1 / 9$, the leaching temperature was $25^{\circ} \mathrm{C}$, the sulfuric acid concentration was $60 \mathrm{~g} / \mathrm{l}$, the rotation speed was $450 \mathrm{r} / \mathrm{min}$, and the leaching time was $4 \mathrm{~h}$ in all experiments. The effect of roasting temperature and time is shown in Figure 3. At $400^{\circ} \mathrm{C}$, the not high recovery of $66.3 \%$ is observed at $2 \mathrm{~h}$. At this temperature, the reaction system was not successful, because the molecules of copper sulfide minerals in the reaction were probably not possessed the enough energy which is needed to. At $600^{\circ} \mathrm{C}$, recovery of copper was nearly constant between 1 - 3 hours. After $3 \mathrm{~h}$ the recovery was increased (54.3\%), but not enough. From Figure 3, it seen that, the high nearly recoveries of copper $(91.1 \%-93.2 \%)$ were observed at temperature range $450^{\circ} \mathrm{C}-550^{\circ} \mathrm{C}$. The significant dissolving degree was at $500^{\circ} \mathrm{C}$ and $3 \mathrm{~h}$ of roasting. The maximum recovery value was observed at $93.2 \%$.

An evaluation of Gibbs energies calculation is showed that most of the above reactions were thermodynamically possible at a low temperature such as from $400^{\circ} \mathrm{C}$ to $600^{\circ} \mathrm{C}$. Table 1 is shown the evaluation of Gibbs energies at $450^{\circ} \mathrm{C}$, $500^{\circ} \mathrm{C}$ and $550^{\circ} \mathrm{C}$ that result of recovery copper was higher than other experiments. 


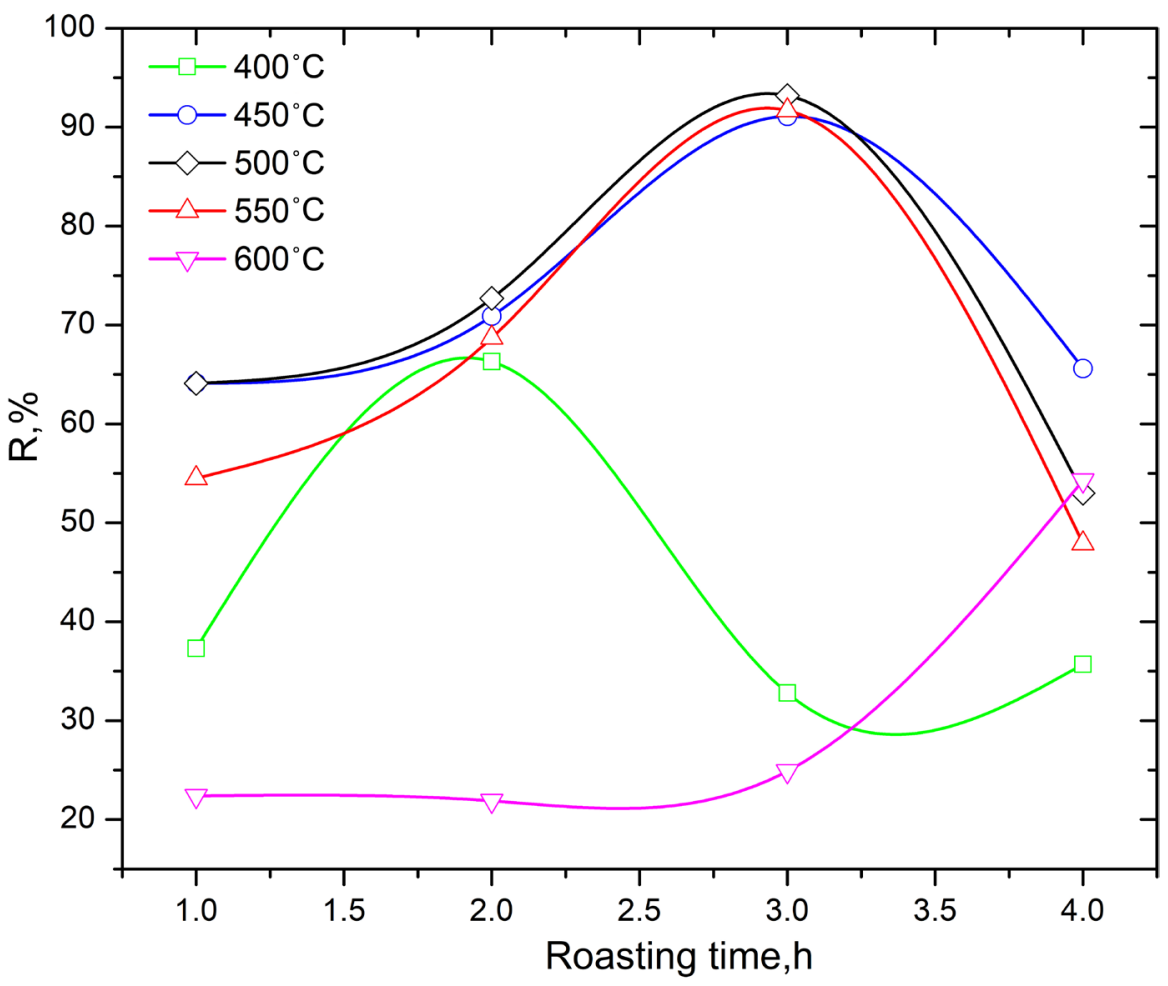

Figure 3. Effect of roasting temperature and time on recovery copper.

Table 1. Evaluation of Gibbs energies of reactionsable.

\begin{tabular}{cccc}
\hline \multirow{2}{*}{ Reaction } & \multicolumn{3}{c}{$\Delta \mathrm{G}^{\circ}, \mathrm{kJ} / \mathrm{mol}$} \\
\cline { 2 - 4 } & $723.15 \mathrm{~K}$ & $773.15 \mathrm{~K}$ & $823.15 \mathrm{~K}$ \\
\hline$(1)$ & -983.80 & -948.44 & -913.08 \\
$(2)$ & -974.65 & -939.41 & -904.17 \\
$(3)$ & -1707.52 & -1644.47 & -1581.42 \\
$(4)$ & -906.88 & -872.59 & -838.30 \\
$(5)$ & -829.35 & -802.11 & -774.87 \\
$(6)$ & -455.62 & -437.72 & -419.81 \\
$(7)$ & -739.62 & -727.12 & -714.62 \\
$(8)$ & -60.40 & -53.23 & -46.06 \\
$(9)$ & -77.52 & -70.48 & -63.43 \\
\hline
\end{tabular}

The recovery of copper into the solution at optimum condition roasting temperature $500^{\circ} \mathrm{C}$, roasting time $3 \mathrm{~h}$, concentrate and potassium chloride 1:0.7 was 93.2\%. Figure 4 and Figure 5 are shown SEM-EDX analysis results on roasting concentrate with $\mathrm{KCl}$ and solid residue after leaching. From Figure 4, it can be seen that roasting cake surface was changed, and the copper sulfide minerals oxidized with $\mathrm{KCl}$, it consists of (wt\%) $30.83 \mathrm{Cu}, 11.03 \mathrm{Fe}, 24.84 \mathrm{~K}, 11.73 \mathrm{~S}, 10.07$ $\mathrm{O}$ and $7.98 \mathrm{Cl}$ from the SEM-EDX analysis.

From SEM-EDX, the solid residue contains (wt\%) 70.5Fe and 21.34O. But, hematite was observed in the solid residues, by XRD analysis. Contents of $1 \% \mathrm{Cu}$ 


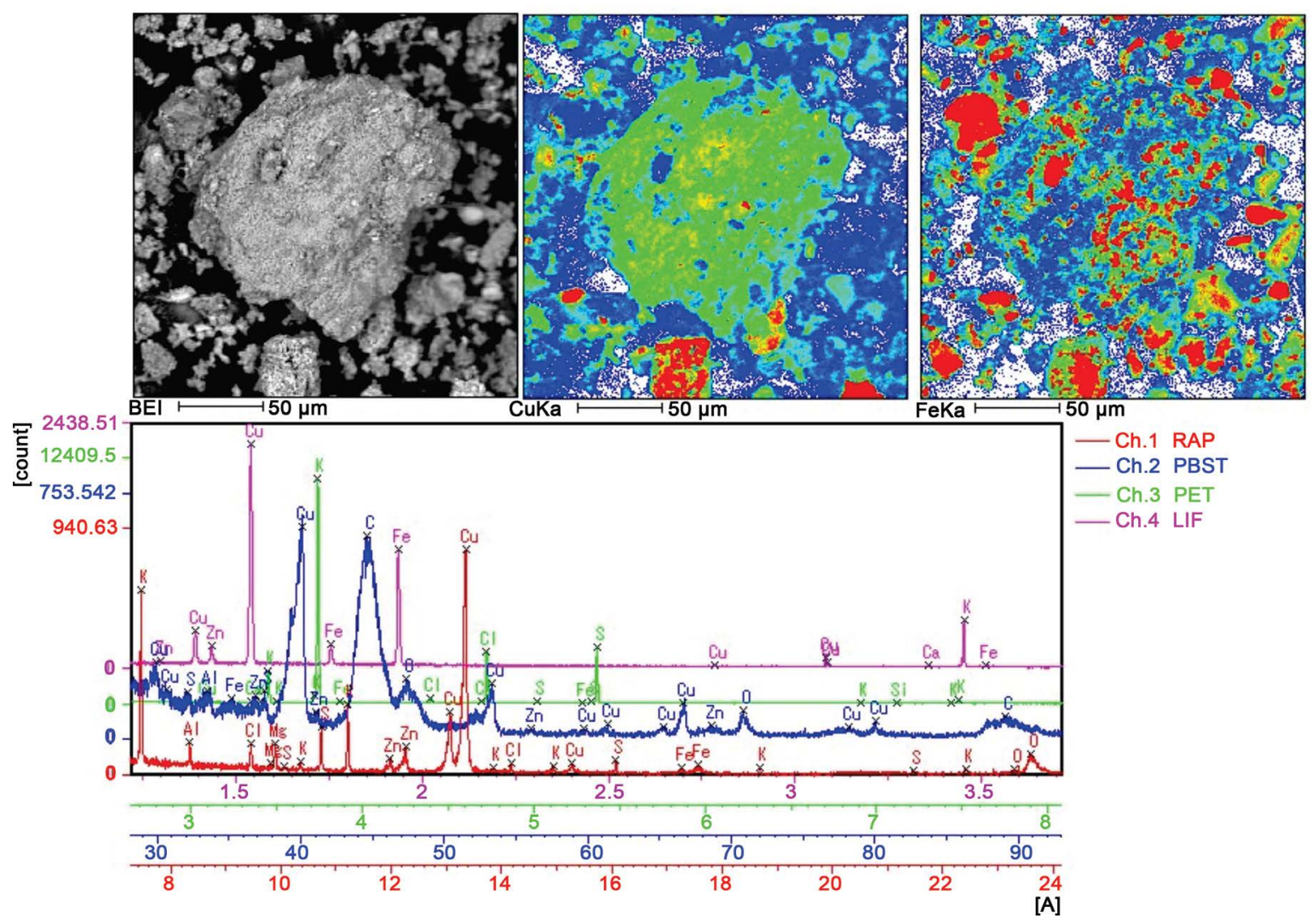

Figure 4. SEM-EDX of copper concentrate after roasting.

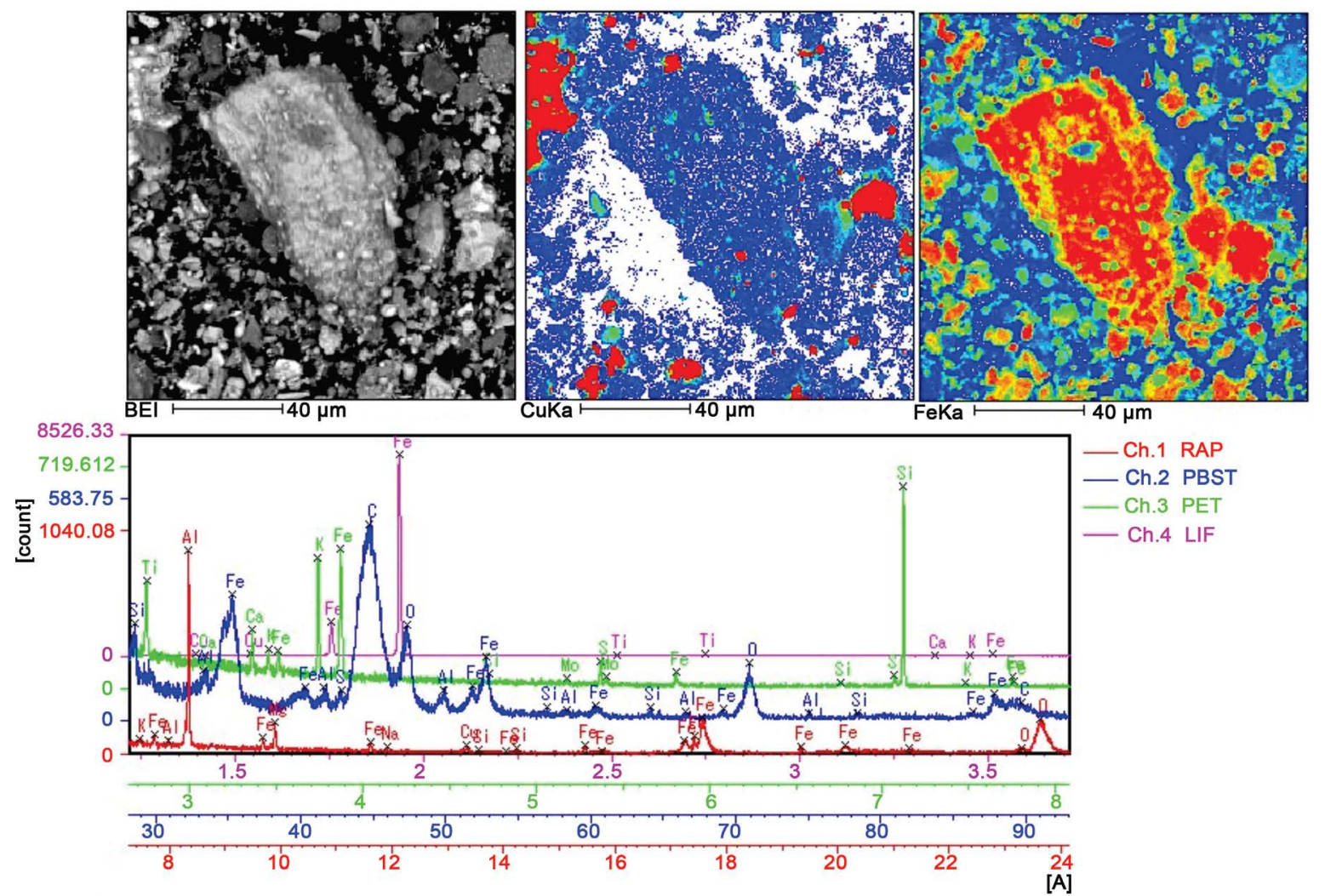

Figure 5. SEM-EDX of solid residue after leaching. 
and $0.31 \% \mathrm{~S}$ in solid residues shows that these elements were transferred to the solution during leaching.

Phases in concentrate were analysed by XRD after $3 \mathrm{~h}$ of roasting at temperature between $400^{\circ} \mathrm{C}-550^{\circ} \mathrm{C}$. From Figure 6 all phase analysis is shown potassium sulfide $\left(\mathrm{K}_{2} \mathrm{SO}_{4}\right)$, copper chloride $\left(\mathrm{CuCl}_{2}\right)$, molysite $\left(\mathrm{FeCl}_{3}\right)$ and lawrencite $\left(\mathrm{FeCl}_{2}\right)$ were in samples. It is seen copper concentrate was oxidized with $\mathrm{KCl}$ according to above reactions. Concerning the XRD analysis after roasting at $400^{\circ} \mathrm{C}$, a potassium chloride was revealed. These results were showed that the roasting process of copper sulfide minerals was not fully oxidized with $\mathrm{KCl}$ at $400^{\circ} \mathrm{C}$.

For defining the mechanism of leaching, the solid residue was examined by XRD (Figure 7). Figure 7(A) shown that the solid residue contains following minerals hematite $\left(\mathrm{Fe}_{2} \mathrm{O}_{3}\right)$, albite $\left(\mathrm{Na}\left[\mathrm{AlSi}_{3} \mathrm{O}_{8}\right]\right)$, and quartz $\left(\mathrm{SiO}_{2}\right)$. The XRD results are shown that the roasting process of copper sulfide minerals was oxidized with $\mathrm{KCl}$ and the oxidized products of copper were leached in sulfuric acidic solution completely.

\section{Conclusions}

Thus, we can conclude the following results according to development of processing the sulfide copper concentrate:

- This study demonstrated the possibility of the combined process for copper recovery at laboratory condition.

- The recovery of copper into the solution at feasible condition of roasting temperature $500^{\circ} \mathrm{C}$, roasting time $3 \mathrm{~h}$, concentrate/potassium chloride weight ratio $1 / 0.7$, leaching time $4 \mathrm{~h}$, leaching temperature of $25^{\circ} \mathrm{C}$ is $93.2 \%$.

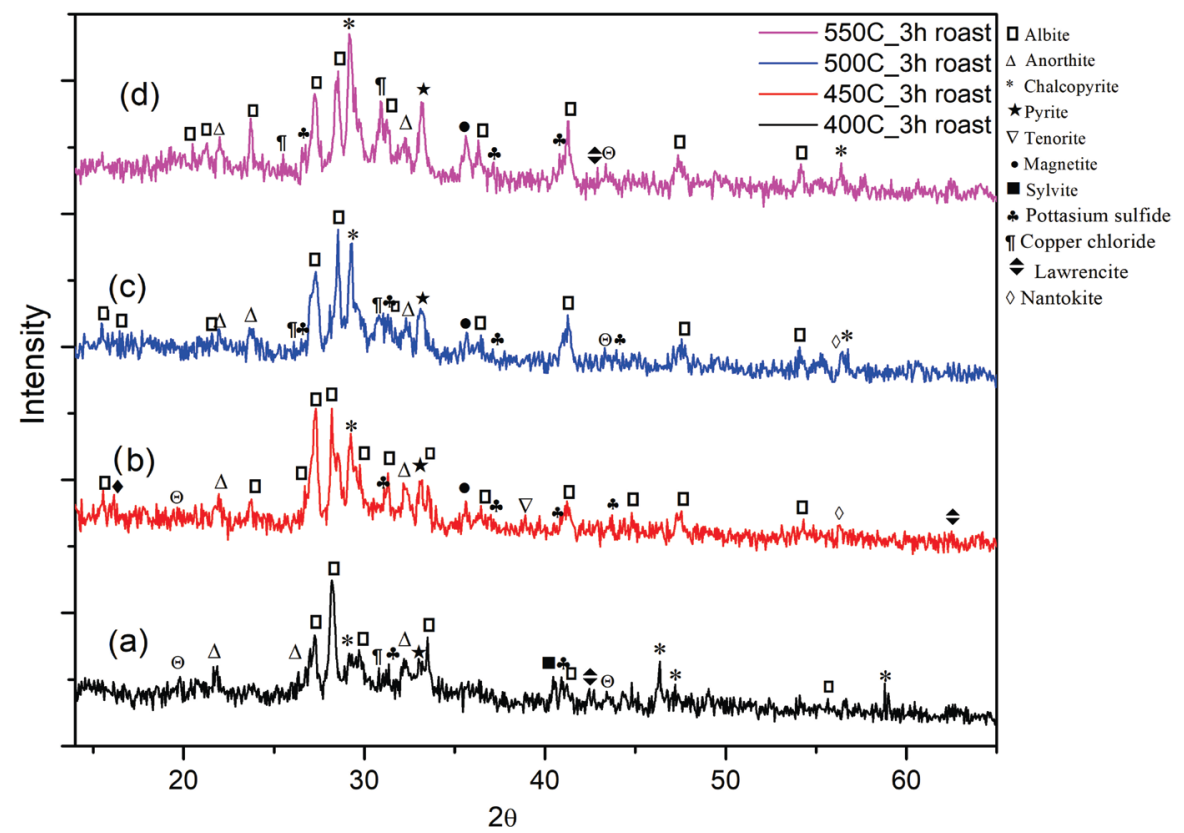

Figure 6. XRD pattern of copper concentrate after roasting at temperature between $400^{\circ} \mathrm{C}-550^{\circ} \mathrm{C}$. (a) $400^{\circ} \mathrm{C}, 3 \mathrm{~h}$ roasted; (b) $450^{\circ} \mathrm{C}, 3 \mathrm{~h}$ roasted; (c) $500^{\circ} \mathrm{C}, 3 \mathrm{~h}$ roasted; (d) $550^{\circ} \mathrm{C}, 3 \mathrm{~h}$ roasted. 


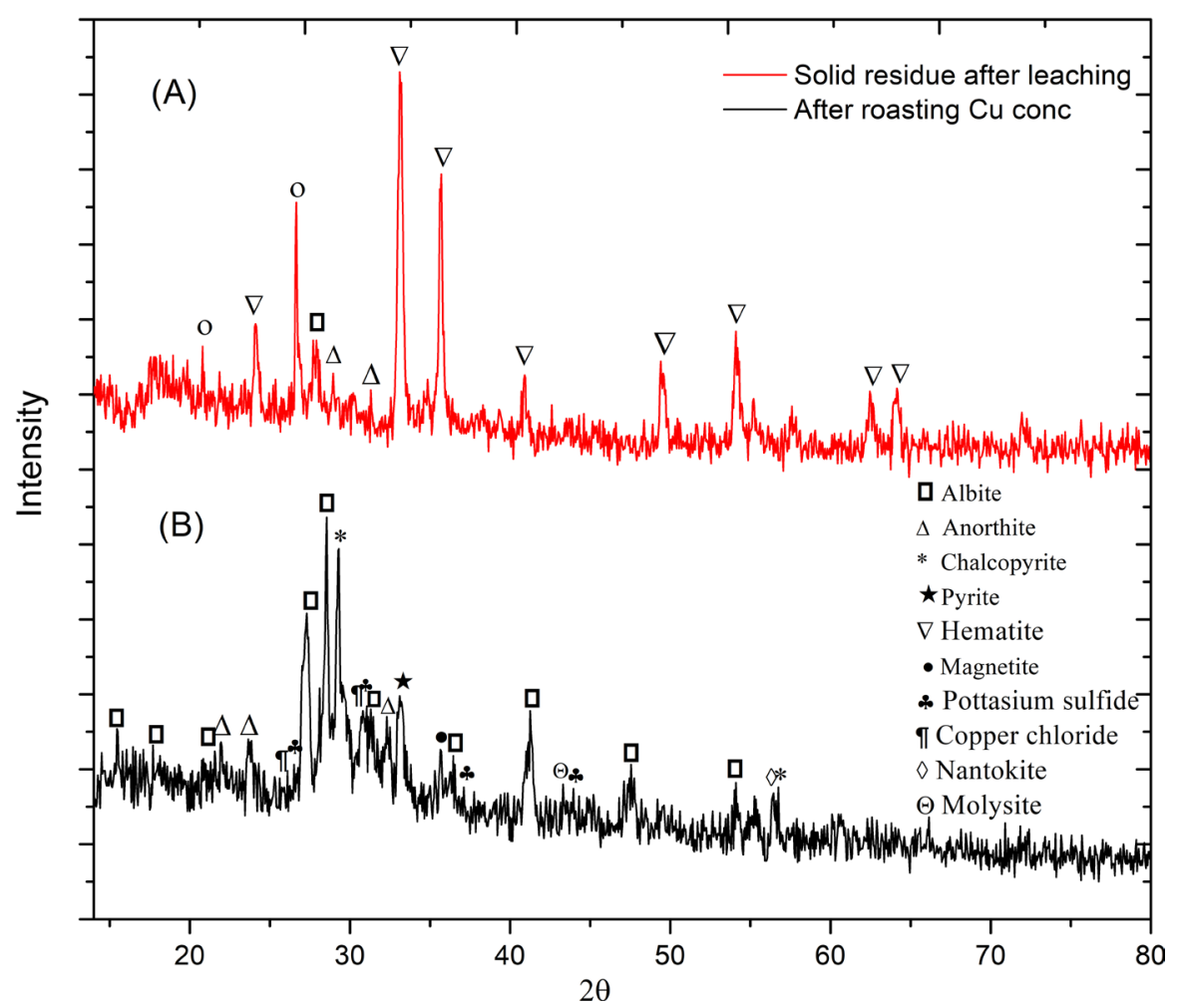

Figure 7. XRD pattern of solid phase after leaching (A), copper concentrate after roasting at $500^{\circ} \mathrm{C}(\mathrm{B})$.

- A high iron and low sulfur contents in solid residue allow us to obtain high-quality copper from leaching solution. The combined method involving low temperature roasting of sulfide copper minerals with potassium chlorides without the formation of sulfurous gases and their evolution into the atmosphere is suggested.

\section{Conflicts of Interest}

The authors declare no conflicts of interest regarding the publication of this paper.

\section{References}

[1] Córdoba, E.M., Muñoz, J.A., Blázquez M.L., González, F. and Ballester, A. (2008) Leaching of Chalcopyrite with Ferric Ion, Part I: General Aspects. Hydrometallurgy, 93, 81-87. https://doi.org/10.1016/j.hydromet.2008.04.015

[2] Watling, H.R. (2013) Chalcopyrite Hydrometallurgy at Atmospheric Pressure: 1. Review of Acidic Sulfate, Sulfate-Chloride and Sulfate-Nitrate Process Options. $\mathrm{Hy}^{-}$ drometallurgy, 140, 163-170. https://doi.org/10.1016/j.hydromet.2013.09.013

[3] Farhad, K.K., Sina, H., Jalil, V. and Abolfazl, B. (2016) Mechanochemical Leaching of Chalcopyrite Concentrate by Sulfuric Acid. International Journal of Minerals, Metallurgy and Materials, 23, 380-388. https://doi.org/10.1007/s12613-016-1247-7

[4] Medvedev, A.S., Tu, S. and Ptitsyn, A.M. (2012) Combined Processing Technology of the Udokan Sulfide Copper Concentrate. Russian Journal of Non-Ferrous Metals, 53, 125-128. https://doi.org/10.3103/S1067821212020095 
[5] Medvedev, A.S. and Tu, S. (2012) Characteristics of Electrochemical Reactions Accompanying Chlorinating Annealing of Copper Sulfide Concentrates. Russian Journal of Non-Ferrous Metals, 54, 1-4. https://doi.org/10.3103/S1067821213010148

[6] Bayer, G. and Wiedemann, H.G. (1992) Thermal Analysis of Chalcopyrite Roasting Reactions. Thermochimica Acta, 198, 303-312. https://doi.org/10.1016/0040-6031(92)85087-C

[7] Chakravortty, M. and Srikanth, S. (2000) Kinetics of Salt Roasting of Chalcopyrite Using KCl. Thermochimica Acta, 362, 25-35. https://doi.org/10.1016/S0040-6031(00)00475-5

[8] Srikanth, S. and Chakravortty, M. (2001) Non-Isothermal Thermoanalytical Studies on the Salt Roasting of Chalcopyrite Using KCl. ThermochimicaActa, 370, 141-148. https://doi.org/10.1016/S0040-6031(00)00776-0 